\title{
TÜRKIYE'NINN BÖLGESEL
}

\section{EKONOMIKK ÖRGÜTLERLE \\ İHRACATI ÜZERINNE ÇEKIMM
Hacettepe Üniversitesi
iktisadi ve Idari Bilimler
Fakültesi Dergisi
Cilt 37, Sayı 2, 2019
s. $193-214$

\section{MODELİ UYGULAMASI: AB DIŞINDA}

\section{ALTERNATİFLER MÜMKÜN MÜ?}

\author{
Fatma AKÇAY \\ Dr. Öğrencisi, Ege Üniversitesi \\ Sosyal Bilimler Enstitüsü \\ fatma_akc@hotmail.com \\ Fatih Refik SAYGILI \\ Prof. Dr., Ege Üniversitesi \\ İktisadi İdari Bilimler Fakültesi \\ İktisat Bölümü \\ fatih.saygili@ege.edu.tr
}

z: Küreselleşme ile uluslararası ticarette
engeller azaltılmış, ülkeler arasındaki
ticari ilişkiler güçlenmiştir. 1980
sonrası bölgeselleşme süreci hız
kazanmış, yeni dünya düzeninde ticari blokların oluşmasına neden olmuştur. $\mathrm{Bu}$ durum Türkiye'nin hangi ticari blokta yer alacağı sorusunu gündeme getirmiştir. Bu çalışmada Çekim Modeli Türkiye'nin farklı bölgesel ekonomik örgütlerle ihracatı üzerine kullanılmış ve Türkiye için $\mathrm{AB}$ dışında başka güçlü alternatiflerin olup olmadığ 1 sorgulanmıştır. Modelde dünya ekonomisinde önemli paylara sahip olan bölgesel entegrasyonlardan AB, NAFTA, APEC, ASEAN, GCC ve AEC bağımsız değişkenler olarak seçilmiştir. Elde edilen sonuçlar Türkiye'nin diş ticaretinde AB'nin vazgeçilmemesi gereken bir partner olduğu ancak aynı zamanda Asya, Ortadoğu ve Afrika ülkeleri ile ticari ilişkilerini geliştirilmesi gerektiğini göstermektedir. Ayrıca imzalanan serbest ticaret anlaşmaları (STA) ve GB'nin ihracat üzerinde olumlu etkileri olduğu ancak GB'nin etkisinin daha fazla olduğu yönündedir.

Anahtar Sözcükler: Küreselleşme, ekonomik örgütler, Avrupa Birliği, dış ticaret, çekim modeli, Gümrük Birliği. 


\section{AN APPLICATION OF GRAVITY \\ MODEL ON TURKEY'S EXPORTS \\ Hacettepe University Journal of Economics and Administrative Sciences WITH REGIONAL ECONOMIC ORGANIZATIONS: ARE THERE

\section{ANY OTHER ALTERNATIVES TO EU?}

Fatma AKÇAY

$\mathrm{PhD}$. Student, Ege University

Graduate School of Social Sciences

fatma_akc@hotmail.com

\section{Fatih Refik SAYGILI}

Prof. Dr., Ege University

Faculty of Economics and Administrative

Sciences

Department of Economics

fatih.saygili@ege.edu.tr
1

bstract: With globalization, the barriers on international trade have been reduced and commercial relations among countries have strengthened. In the post 1980 period, regionalization process accelerated and led to the formation of trade blocs in the new world order. This situation has raised the question of which trade bloc Turkey will take part in. In this paper, Gravity Model is used on Turkey's exports with different regional economic organizations and it is questioned whether there are any strong alternatives to EU. In the model EU, NAFTA, APEC, ASEAN, GCC and AEC are chosen as dependent variables since these regional integrations have significant shares in the world economy. The results show that the EU seem to be an indispensable partner for Turkey but Turkey's trade relations with Asian, Middle East and African countires need to be further improved. Moreover, the free trade agreements (FTA) and CU have positive effects on Turkey's exports, but still CU's effect is more significant.

Keywords: Globalization, economic organizations, European Union, Foreign Trade, gravity model, customs. 


\section{Gİiș}

Akademik literatürde küreselleşme kavramının bir süreci, durumu, sistemi, gücü ve dönemi ifade ettiği konusunda ortak bir görüş hâkimdir (Steger, 2006: 24). Birçok alanda (siyasal, askeri, çevresel, kültürel $v b$.) etkisini gösterdiği kaçınılmaz bir gerçek halini alan kavramın ekonomi üzerindeki etkileri de zaman içinde ağırlık kazanmıştır. Küreselleşme olgusunun gelişmesiyle birlikte bölgeselleşme kavramı gündeme gelmiş, ülkeler bulundukları bölgede ekonomik gelişme sağlamak, tek pazar oluşturmak ve zorlaşan rekabet ortamında ayakta kalmak için birleşme yoluna gitmişlerdir. Bu açıdan bakıldığında bölgeselleşme, hem küreselleşmenin bir sonucu hem de küreselleşme karşısında bir direnme gücü olarak karşımıza çıkmaktadır.

Küresel dönüşüm ile birlikte ekonomik ilişkilerde korumacılık anlayışı zamanla yerini serbest ticaret görüşüne bırakmış ancak ticari ilişkiler her zamankinden daha bağımlı ve karmaşık bir hal almıştır. Özellikle II. Dünya Savaşı sonrasında sosyal, ekonomik, askeri ve politik uluslararası kurumlar aktör olarak sistemde yerlerini almıştır. Bu aktörlerin başında uluslararası ekonomik örgütler gelmektedir. Günümüz ekonomisinde bu örgütler tüm ticari ilişkileri belirleyecek hatta geleceğe yön verecek kadar güçlenmiştir. Ortaya çıkan bu durum özellikle gelişmekte olan ve az gelişmiş ülkeler için daha fazla önem arz etmektedir. Ülkelerin hangi ticari blokta yer alacağ veya hangi ticari blokla ticari ilişkilerini geliştirmesi gerektiği süregelen tartışma konular arasında ön saflarda yer almıştır.

Gelişmekte olan ülkeler kategorisinde yer alan Türkiye, geçmişten günümüze değişik ekonomi politikaları benimsenmiş ve benimsenen bu politikalar küresel ekonomi ile paralellik göstermiştir. 1960'lı yıllardan itibaren uygulamaya konulan ithal ikameci sanayileşme politikaları "24 Ocak Kararları” ile yerini dışa dönük, ihracata dayalı sanayileşme politikalarına bırakmıştır. 1980 yılında alınan bu karar Türkiye’nin dış ticaretinde bir dönüm noktası olmuş, gelecekte atılması planlanan adımlarının temelini oluşturmuştur. Diğer bir kilometre taşı ise 1996 yılında Türkiye'nin Avrupa Birliği (AB) yolunda ilişkileri bir adım öne taşıyan Gümrük Birliği Anlaşması (GB) ile gerçekleşmiştir. Gerek 1980 gerekse 1996 yılında alınan bu kararlar Türkiye'nin dünya ekonomisinde daha sağlam bir yer ve daha sıkı ilişkiler ağı içinde olmasını sağlamak adına atılııs adımlardır.

Küresel eğilimlerle paralel olarak ekonomide yapısal dönüşümler gerçekleştiren Türkiye zamanla küresel ve bölgesel ekonomik örgütlerin önemi kavramış, ekonomik ilişkilerin daha kapsamlı bir hale gelmesi için diş ticaret politikası oluşturmuştur. Bu konuda en büyük çaba $\mathrm{AB}$ üyelik mücadelesinde gösterilmiştir. 1959 yılında başlayan üyelik başvurusu 1999 yılında Helsinki Zirvesi'nde alınan kararla Türkiye'nin aday ülke ilan edilmesi ile seviye atlamış, son olarak 2005 yılında tam üyelik müzakerelerinin başlamasıyla sonuçlanmıştır. 
AKÇAY, SAYGILI | An Application of Gravity Model on Turkey's Exports with Regional Economic...

Ancak son dönemde AB ile yaşanan (gerek siyasi gerekse ekonomik) sorunlar nedeniyle ilişkiler soğuk bir ortamda seyretmeye başlamış, bu süreçte alternatif bir örgütün varlığı sürekli olarak gündeme getirilerek sorgulanmıştır. Türkiye 2002 yılında Kuzey Amerika Serbest Ticaret Antlaşması (NAFTA), 2015 yılında ise Güneydoğu Asya Uluslar Birliği'ne (ASEAN) üyelik istediğini üst makamlarca dile getirmiş, bu istek taraflarca olumlu karşılanmamıştır. Bu konuda bahsi geçen diğer örgütler Şanghay İşbirliği Örgütü (Şiö) ve Avrasya Ekonomik Birliği (AEB)'dir. 2001 yllında kurulmuş olan ŞiÖ, gelişim sürecini henüz tamamlamamış olmakla birlikte ekonomik işbirliğinden ziyade üye ülkeler arasındaki siyasi amaçlara (terörizmle mücadele, kaçakçılık, kültüre işbirliğii..) hizmet etme amacını taşımaktadır (Özdemir, BBC, E.T.: 22.11.2016). Gümrük birliği aşamasıyla kurulmuş olan AEB ise zamanla mal, hizmet, sermaye ve işgücü dolaşımını serbest hale getirmeyi hedeflenmektedir. Örgüt Avrasya'da yer alan diğer ülkeleri de kapsayacak şekilde (AB benzeri) ulus-üstü bir yapıya bürünmeyi amaçlamaktadır (Tüfekçi, E.T.: 15.02.2016). Türkiye hâlihazırda AB ile bir gümrük anlaşması imzalamıştır, bu nedenle hukuki olarak başka bir birlikle GB anlaşmasını imzalayamaz. Bu nedenle nihai hedefleri daha çok siyasi birlik oluşturmak olan örgütlerin $\mathrm{AB}$ karşısında alternatif olarak lanse edilmesi doğru bir yaklaşım değildir. $\mathrm{Bu}$ nedenle günümüzde etkinliği devam eden ekonomik işbirliği ve bütünleşmeler düşünüldüğünde Türkiye için $\mathrm{AB}$ karşısında tam anlamıyla alternatif olarak düşünülebilecek bir örgüt bulunmamaktadır. Ancak bahsi geçen örgütlerle kurulacak yakın ilişkilerin Türkiye için tamamlayıcı güç olacağı da yadsınamaz bir gerçektir.

\section{TÜRKIYE DIŞ TICCARETINDE BÖLGESEL EKONOMIK ÖRGÜTLERIN YERİ}

Birden çok kıtayı kapsayan, yükselen değerleri dikkate alan ve çok yönlü bir dış ticaret politikası gerekliliğine uygun olarak yeni bir rota çizilmiş, açılım planları yürürlüğe konulmuştur. Özellikle 1990'lı yıllarda başlayan çok yönlü ekonomi politikası $2000^{\prime} l i$ yıllarda devam etmiş, bu politika uyarınca eski ilişkiler gözden geçirilmiş ve yeni ilişikler kurmak adına çeşitli adımlar atılmıştır. Çalışma kapsamında bölgesel ekonomik örgütlerden ${ }^{1}$ Türkiye'nin üye olmadığı AB, NAFTA, Asya Pasifik Ekonomik İşbirliği (APEC), ASEAN, Körfez İşbirliği Teşkilatı (GCC), Afrika Ekonomik Topluluğu (AEC) seçilmiştir. Çok kutuplu ekonomik düzende kendine yer edinmiş ve dünya ekonomisinde belirli paylara sahip olan bu bölgesel örgütlerin konumlarının yanı sıra ekonomik geleceğin şekillenmesinde üstlenecekleri rollerde seçilmelerinde etkili olmuştur. Üye olunmayan birliklerin seçilmesindeki temel amaç ise Türkiye'nin geçmişten günümüze bu birliklerle ekonomik ilişkilerini geliştirmek adına attığı adımları incelemek ve gelecekte atılması planlanan adımları açıklamaktır. 
Seçili ekonomik örgütlerle ticari ilişkiler süreci incelendiğinde en uzun ve meşakkatli sürecin $\mathrm{AB}$ 'ye ait olduğu görülmektedir. $\mathrm{AB}$ ile ticari ilişkilerde hukuki temel oluşturan Ankara Antlaşması 1963 yılında imzalanmış, antlaşma şartları uyarınca taraflar arasında GB 1996 yllında yürürlüğe girmiştir. 1999 yılında Helsinki Zirvesi’nde Türkiye aday ülke ilan edilmiş, 2005 yılından günümüze tam üyelik müzakereleri devam etmekle birlikte henüz bir ilerleme kaydedilememiştir. Türkiye, Atlantik Pasifik ülkeleri arasında ekonomik işbirliği oluşturmayı amaçlayan APEC'in üyesi olmadığı gibi birlik ile ticaretini kolaylaştıracak herhangi bir antlaşmaya da sahip değildir. Dış ticaret hacminde önemli yer tutan APEC'le ticari ilişkiler ülkeler bazında yürütülmektedir. Özellikle Rusya, ABD, Çin gibi ekonomisi güçlü devletlerin yer aldığı birlikte ortaya çıkacak gelişmeler yakından takip edilmektedir.

Diğer bir önemli bütünleşme olan NAFTA ile ticari ilişkiler Türkiye için önem arz etmektedir. Ancak taraflar arasında hali hazırda serbest ticaret anlaşması veya tercihli ticaret anlaşması bulunmamaktadır. Buna mukabil Türk ihracatçıları ABD pazarına GTS (Genelleştirilmiş Tercihler Sistemi) ile giriş yapmaktadır. Asya kıtasındaki önemli bütünleşmeler arasında yer alan ASEAN'ın Türkiye üyesi olmak istemiş, ancak birlik tarafından bölgesel yakınlık ve kültürel benzerliğin altı çizilerek reddedilmiştir. Taraflar arasında 2010 yılında Dostluk ve İşbirliği Antlaşması imzalanmış, Türkiye 2013 yılında toplantılara gözlemci statüsü ile katılma hakkı elde edilmiştir. İlişkilerde son gelişme 2017'de düzenlenen toplantıda Türkiye'nin Sektörel Diyalog Ortağı ilan edilmesiyle gerçekleşmiştir. Asıl amaçlanan taraflar arasındaki ticareti geliştirecek olan Diyalog Ortaklığı Anlaşması'nın imzalanmasıdır.

Batılı ülkeler tarafindan rol model olarak gösterilen ve doğu - batı arasında köprü konumunda olan Türkiye ile GCC ülkelerine arasındaki ticari ilişkiler 2005 yılında Serbest Ticaret Çerçeve Anlaşması ile hukuki zemine oturtulmuş, 2008 yılında Cidde'de düzenlenen toplantıda "Stratejik Ortak" ilan edilmiştir. 2009 yılında Davos Zirvesi'nde yaşanan gelişmeler Türkiye'nin bölgedeki popülaritesini arttırmış, taraflar arasındaki yakın ilişkiler ticaret hacmini de olumlu etkilemiştir. Afrika kıtası ile ticari ilişkilerin seyri açılım planı ile gelişme göstermiş olup 2005 yılı Türkiye'de Afrika yılı olarak kutlanmış, aynı yıl Türkiye Afrika Birliği’nde gözlemci ülke statüsü kazanmıştır. Ayrıca ilişkilerde yaşanan diğer bir gelişme 2008 yılında Türkiye'nin stratejik ortak ilan edilmesiyle gerçekleşmiştir. 


\section{Şekil 1. Türkiye Dış Ticaretinde Ekonomik Örgütlerin İhracat - İthalat Dağılımı} $(1996-2016)$
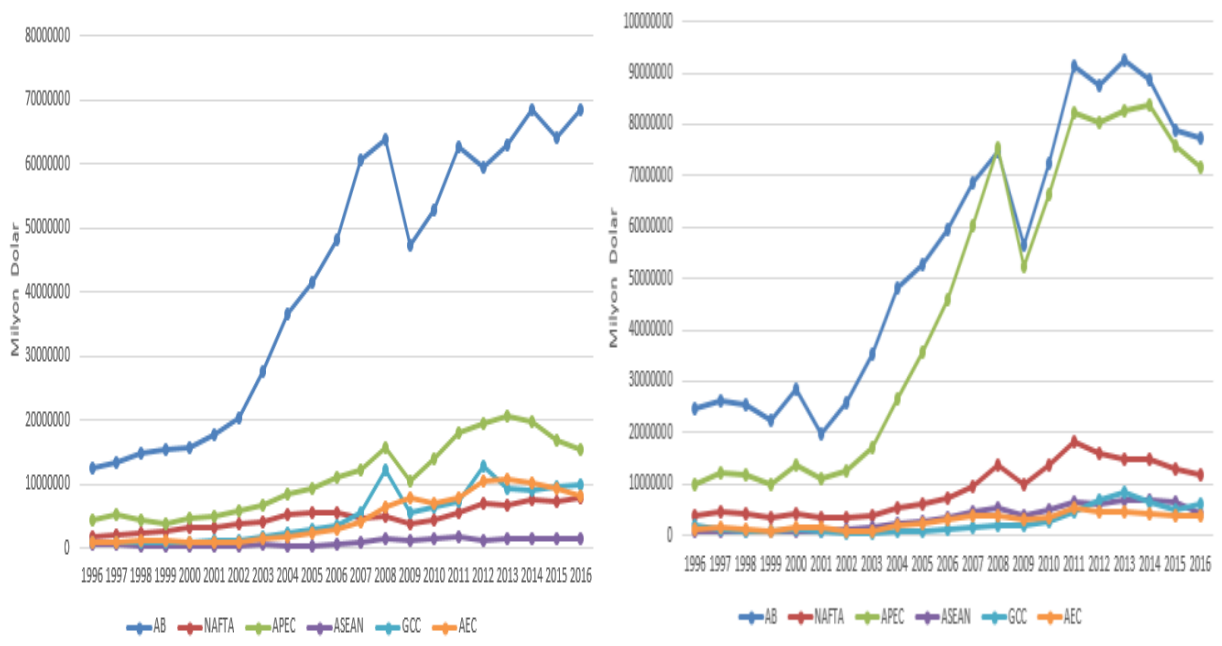

Kaynak: TÜIK

Yapılan çalışmaların günümüz dış ticaretindeki yansımalarını görmek için GB sonrası hem ihracat hem de ithalat verileri ele alınmış, verilerinin yıllar içerisinde gösterdiği değişim Şekil 1 yardımıyla ortaya konulmaya çalışılmıştır. 1996 - 2016 yılı verileri incelendiğinde hem ihracat hem de ithalatta diğer ekonomik örgütlere kıyasla $\mathrm{AB}$ ile ilişkilerin daha yoğun olduğu görülmüştür. İstisnai yıllar dışında ticaret hacminde yükselen bir trend yakalanmış, Türkiye aleyhine devam eden süreç 2008 krizi sonrası dalgalanmalarla devam etmiştir. Seçili örgütler arasında $A B$ 'den sonra Türkiye'nin en yüksek ticaret hacmine sahip olduğu örgüt APEC'tir. Yıllar içerisinde artan dış ticaret hacmi Türkiye aleyhine gelişme göstermiştir. İhracat verileri incelendiğinde $\mathrm{AB}$ ile arasında büyük bir fark olduğu görülmekle birlikte ihracat hacminde zaman içerisinde artış yaşanmıştır. İthalat verileri ele alındığında ise AB kadar önemli bir konumu işgal eden APEC'le ilişkilerin AB ile paralel bir seyirde devam ettiği görülmüştür.

NAFTA ile ülkeler bazında yürütülen ticari ilişkiler küresel krizle birlikte düşüşe geçmiştir. İhracat verileri incelendiğinde kriz öncesinde artan ticaret hacminin krizle birlikte kısa süreli düştüğü, kriz sonrası toparlanma evresiyle eski ivmenin tekrar yakalandığı gözlenmiştir. Son zamanlarda açılım planları yapılan Asya kıtasının önemli örgütlerinden ASEAN ile ticaret hacmi diğer örgütlerle kıyaslandığında en düşük seviyededir. Yıllar içerisinde ticaret hacmi Türkiye aleyhine gelişme göstermekle birlikte ASEAN ile ticari ilişkiler istenilen düzeyde değildir. 
Türkiye'nin son yıllarda ticaret fazlası vererek ticaret politikasını yoğunlaştırdığı birlikler GCC ve AEC'dir. Yakın coğrafyada yer alan Körfez ülkelerinin bölgede ulaşmak istedikleri barış ve istikrar ortamı Türkiye için de önem arz etmektedir. Diğer birliklerden farklı olarak birikmiş sermaye ve yüksek enerji geliri nedeniyle Türkiye, son y1llarda bölgeye yönelik ticari ilişkilerini geliştirmiştir. İhracat verileri 1996 yllından günümüze artış göstermiş, yaşanan ayaklanmalar ve krizler ise ticaret hacmini olumsuz etkilemiştir. Bağımsızlık sonrası kıtada istikrar ve sürdürülebilir kalkınma için mücadele veren AEC, Türkiye tarafindan desteklenmektedir. İhracat verileri incelendiğinde özellikle 2000 sonrası uygulanan açılım politikaları etkisini göstermiş, kriz dönemine kadar ihracat verilerinde artış trendi yakalanmıştır. İthalat verilerinde ise gözle görülür bir değişim gerçekleşmemiştir.

Tablo 1. Türkiye Dış Ticaretinde Ekonomik Örgütlerin Payı

\begin{tabular}{|c|c|c|c|c|c|c|c|c|c|c|c|c|}
\hline & \multicolumn{6}{|c|}{ İHRACAT (\%) } & \multicolumn{6}{|c|}{ İTHALAT (\%) } \\
\hline & $\mathrm{AB}$ & APEC & NAFTA & ASEAN & GCC & $\mathrm{AEC}$ & $\mathrm{AB}$ & APEC & NAFTA & ASEAN & GCC & AEC \\
\hline 1996 & 54 & 18 & 8 & 3 & 3 & 3 & 57 & 22 & 9 & 1 & 4 & 3 \\
\hline 1997 & 51 & 20 & 8 & 3 & 4 & 3 & 54 & 25 & 10 & 1 & 3 & 3 \\
\hline 1998 & 55 & 16 & 9 & 0.9 & 3 & 3 & 55 & 25 & 9 & 2 & 2 & 2 \\
\hline 1999 & 58 & 14 & 10 & 0.9 & 3 & 2 & 55 & 24 & 8 & 2 & 2 & 2 \\
\hline 2000 & 57 & 17 & 12 & 0.8 & 3 & 2 & 52 & 25 & 7 & 2 & 2 & 3 \\
\hline 2001 & 56 & 16 & 11 & 0.8 & 3 & 3 & 48 & 26 & 8 & 2 & 2 & 4 \\
\hline 2002 & 57 & 16 & 10 & 1 & 3 & 2 & 50 & 24 & 7 & 2 & 0.5 & 1 \\
\hline 2003 & 58 & 14 & 8 & 1 & 4 & 2 & 55 & 24 & 6 & 2 & 0.5 & 1 \\
\hline 2004 & 58 & 14 & 8 & 0.6 & 4 & 3 & 49 & 27 & 5 & 2 & 0.6 & 2 \\
\hline 2005 & 57 & 13 & 7 & 0.5 & 4 & 3 & 45 & 30 & 5 & 2 & 0.7 & 2 \\
\hline 2006 & 56 & 13 & 7 & 0.8 & 5 & 3 & 43 & 33 & 5 & 2 & 0.8 & 2 \\
\hline 2007 & 57 & 11 & 4 & 0.8 & 9 & 4 & 40 & 35 & 6 & 3 & 0.9 & 2 \\
\hline 2008 & 48 & 12 & 4 & 1 & 9 & 5 & 37 & 37 & 7 & 3 & 1 & 2 \\
\hline 2009 & 46 & 10 & 4 & 1 & 5 & 7 & 40 & 37 & 7 & 3 & 1 & 2 \\
\hline 2010 & 46 & 12 & 4 & 1 & 5 & 6 & 39 & 36 & 7 & 3 & 1 & 2 \\
\hline 2011 & 46 & 13 & 4 & 1 & 5 & 6 & 38 & 34 & 7 & 3 & 2 & 2 \\
\hline 2012 & 40 & 13 & 5 & 0.8 & 8 & 7 & 37 & 34 & 7 & 3 & 3 & 2 \\
\hline 2013 & 42 & 14 & 4 & 0.9 & 6 & 7 & 37 & 33 & 6 & 3 & 3 & 2 \\
\hline 2014 & 43 & 13 & 5 & 0.9 & 6 & 6 & 37 & 35 & 6 & 3 & 3 & 2 \\
\hline 2015 & 44 & 12 & 5 & 1 & 7 & 6 & 38 & 37 & 6 & 3 & 2 & 2 \\
\hline 2016 & 48 & 11 & 5 & 1 & 6 & 5 & 39 & 36 & 6 & 2 & 3 & 2 \\
\hline
\end{tabular}

Kaynak: TÜIKK (Birlik üyesi ülkelerin belirli yıllara ait bulunamayan ihracat-ithalat verileri sıfir kabul edilerek hesaplanmıştrr. 
1996-2016 yıllarını kapsayan Türkiye dış ticaretinde ekonomik örgütlerin payının incelendiği Tablo 1'de benzer sonuçları işaret etmektedir. İlk olarak taraflar arasında yaşanan tüm olumsuzluklara paralel olarak AB'nin dış ticaretteki payı azalmıştır. 1996 yılında Türkiye'nin toplam ihracatının \%54'ünü oluşturan AB, 2016 yılı son verilerinde \%48'ini oluşturmaktadır. 1996 yılında GB'nin tam anlamıla yürürlüğe girmesiyle birliğin toplam ithalattaki payı $\% 57$ düzeyinde (en yüksek seviye) gerçekleşirken, bu oran 2016 yllında \%39 düzeyine düşmüştür. Sonuç itibariyle zaman içerisinde AB'nin hem ihracatta hem ithalatta sahip olduğu payın azaldığı görülmekle birlikte Türkiye'nin en büyük ticari ortağı konumunu sürdürdüğü gözlenmiştir. APEC ülkeleri 1996 yllında Türkiye toplam ihracatının \%18'ini oluştururken, 2016 y1lı son verilerinde ise \%11'ini oluşturmaktadır. Birliğin toplam ithalattaki payı 1996 yılında $\% 22$ düzeyinde iken 2016 yılında $\% 36$ düzeyine ulaşmıştır. Özellikle ithalat verileri dikkate alındığında APEC'in en az AB kadar önem arz ettiği görülmektedir.

NAFTA 1996 yılında Türkiye'nin toplam ihracatının \%8'ini oluştururken bu oran özellikle ekonomik kriz sonrası düşüşe geçmiş, son olarak 2016 yllındaki payı $\% 5$ düzeyinde gerçekleşmiştir. İhracatla paralel olarak ilerleyen ithalat verileri incelendiğinde özellikle 2008 ve 2011 yıllarında krize bağlı olarak belirgin düşüşler yaşandığı gözlenmiştir. 1996 yllında toplam ithalatta pay1 \%9 olan birliğin 2016 yılındaki payı $\% 6$ düzeyinde gerçekleşmiştir. Şekil 1'de görüldüğü gibi gerek ihracat gerekse ithalat verilerinde ASEAN diğer örgütlerle karşılaştırıldığında toplam ticaret hacmi en düşük seviyede olan örgüttür. 1996 yılında toplam ihracatın \%3'ünü oluşturan birliğin toplam ihracattaki payı 2005 yllında $\% 0.5$ seviyesine kadar düşmüştür. Son olarak 2016 yılında \%1 düzeyinde gerçekleşmiştir. 1996 yllında toplam ithalattaki payı $\% 1$ düzeyinde olan birlik, yıllar içerisinde ithalattaki payını kademeli olarak arttırmıs, 2016 yllında $\% 2$ düzeyine ulaşmıştır.

GCC, 1996 y1lında toplam ihracatın \%3'ünü oluştururken 2016 yılında bu oran \%6 düzeyine gerçekleşmiştir. İthalat verileri ele alındığında 1996 yılında toplam ithalatın \%4'ünü oluştururken bu oran 2016 yılında \% 3 düzeyinde gerçekleşmiştir. Gerek ihracat gerekse ithalat verileri yıllar içerisinde dalgalı bir seyir izlediği görülmekle birlikte bu durumun temel neden bölgede yaşanan siyasal istikrarsızlık olarak ifade edilmektedir. AEC, 1996 yllında toplam ihracatın \%3'ünü oluştururken 2016 yllı verilerine göre bu pay $\% 5$ düzeyinde gerçekleşmiştir. İthalat verilerinde incelendiğinde bu dönem aralı̆̆ında artış yaşanmasına rağmen gözle görünür bir değişim gerçekleşmemiştir. 1996 yllında toplam ithalatın \%3'ünü oluşturan birliğin 2016 yılına ait ithalattaki pay oranı $\% 2$ düzeyinde gerçekleşmiştir. 


\section{2. ÇEKIMM MODELI}

Literatürde ülkelerin küresel düzeyde sahip oldukları dış ticaret potansiyelini ortaya koymak ve uluslararası ticaret akımını incelemek için "Çekim Modeli" kullanımı yaygınlaşmıştır. $\mathrm{Bu}$ nedenle çalışmanın devamında yukarıda bahsi geçen birliklerin Türkiye ihracatındaki potansiyelleri çekim modeli kullanılarak analiz edilmiştir. Ayrıca modele Serbest Ticaret Anlaşması (STA) ve GB kukla değişkenler olarak eklenerek imzalanan antlaşmalar arasında karşıllaştırma yapma imkânı sağlanmıştır.

Çekim modelinin temeli 17. yy Sir Isaac Newton tarafından ortaya atılan "Genel Çekim Yasası"na dayanmaktadır. Yasaya göre iki cisim arasındaki çekim kuvveti cisimlerin kütleleriyle doğru, aralarındaki uzaklı̆̆ın karesi ile ters orantılıdır. Uluslararası ticaret akımlarını incelemek için ilk kez 1962 yılında Jan Tinbergen tarafından kullanılan model, iki taraflı ticaret analizini ülkelerin ekonomik büyüklükleri ve aralarındaki coğrafi mesafeye dayandırmaktadır. Buna göre ülke ekonomilerinde meydana gelen büyüme ve coğrafi mesafenin kısa olması ülkeler arasındaki ticaret hacminde artışa neden olmaktadır.

$$
\begin{aligned}
& \mathrm{E}_{\mathrm{ij}}=\alpha_{0} \frac{\mathrm{Y}_{\mathrm{i}} \mathrm{Y}_{\mathrm{j}}}{\mathrm{D}_{\mathrm{ij}}} \\
& \mathrm{E}_{\mathrm{ij}}=\mathrm{i} \text { ülkesinden } \mathrm{j} \text { ülkesine gerçekleştirilen ticaret } \\
& \mathrm{Y}_{\mathrm{i}}=\mathrm{i} \text { ülkesine ait ekonomik büyüklük } \\
& \mathrm{Y}_{\mathrm{i}}=\mathrm{j} \text { ülkesine ait ekonomik büyüklük } \\
& \mathrm{D}_{\mathrm{ij}}=\mathrm{i} \text { ülkesi ile j ülkesi arasındaki uzaklık }
\end{aligned}
$$

Son yıllarda ticari ilişkilerin analizinde kullanılan model bazı avantajları da bünyesinde barındırmaktadır. Bunlardan ilki model için gerekli verilerin elde edilmesinde herhangi bir zorlukla karşılaşılmaması ve verilerin güvenirliğinden emin olunmasıdır. İkinci neden ise standart (basit) çekim modelinden daha iyi sonuçlar almak veya eksiklerinin giderilmesinin sağlanmak için yeni değişkenlerin ilave edilebilmesinin (genişletilmesinin) mümkün olmasıdır. Modele eklenen değişkenlerin (ortak dil, ortak sınır, ortak para birimi, gümrük birliği, serbest ticaret anlaşması, siyasi faktörler, krizler...) ticareti artırıcı yönde etki göstermesi tahmin ediliyorsa pozitif, ticareti engelleyici yönde etki göstermesi tahmin ediliyorsa negatif sonuçlanması beklenmektedir. Çekim modeli ülkelerin küresel ticaret potansiyelini ortaya koymakta kullanıldığı gibi iki ülke arasında yapılacak anlaşmaların ticaret üzerindeki etkisini incelemek içinde kullanılmaktadır (Karagöz, Karagöz, 2009: 131). 


\section{1. Çekim Modeline İlişskin Ampirik Çalışmalar}

Literatürde ilk defa ticaret akımlarını inceleyen Tinbergen 1958 yılı verilerini kullanarak 18 ülke için daha sonra 1959 yılı verilerini kullanarak 42 ülke için modeli test etmiştir. Elde ettiği bulgulara göre ticari anlaşmalar, coğrafi- kültürel yakınlık, GSYİH büyüklüğü ülkeler arasındaki ticareti olumlu etkilerken mesafe olumsuz etkilemektedir.

Poyhonen (1963), Tinbergen'den sonra çekim modelini diş ticarette kullanan ilk yazardır. Poyhonen ticaret hacminin, ticari ortakların milli gelirlerinin artan bir fonksiyonu ve ülkeler arasındaki uzaklığın azalan bir fonksiyonu olarak tahmin edilebileceğini ileri sürmüştür. Uzaklık, taşıma maliyetinin yerine geçmiştir.

Linnemann (1966), çekim modeli için bazı kuramsal önermeler geliştirerek Tinbergen'in sunduğu temel yapıya eklemeler yapmıştır. Tanımlanan faktörlerin, ticaret akımlarını açıklamada sahip oldukları ağırlıkları ölçmeyi amaçlamış ve toplam milli hâsıla içindeki yurtiçi talebin payını belirten, nüfus büyüklüğü gibi ek değişkenleri tanıtarak, çekim modelini genişletmiş̧ir.

Aitken (1973), 1951-1967 dönemi için yatay kesit veri analizi yapılmıştır. Genişletilmiş çekim modeli kullanılarak Avrupa Ekonomi Topluluğu (EEC) ve Avrupa Serbest Ticaret Birliği’nin (EFTA) Avrupa ülkelerinin ticareti üzerindeki etkisini tahmin etmiştir.

Porojan (2001), AB(15) - OECD (7) ülkelerini kapsayan çalışma 1995 yılı için kesit veri analizi yapılarak oluşturulmuştur. Çalışmada çekim modeli ihracat ve ithalat için ayrı ayrı kurulmuş, böylece $\mathrm{AB}$ ve bazı potansiyel üyeler arasındaki ikili ticaret akışını incelemiştir.

Nowak-Lehman ve Martinez-Zarzoso (2003), MERCOSUR ve AB ülkeleri arasındaki ticareti 1988-1996 dönemi için çekim modelini kullanarak analiz edilmiştir. GSYİH büyüklüğünün dış ticareti pozitif etkilerken ihracatı yapan ülke nüfusunun ihracat üzerinde negatif, ithalatı yapan ülke nüfusunun ise ihracat üzerinde pozitif etkisi olduğu ortaya konmuştur.

Antonucci ve Manzocchi (2006), 1967-2001 dönemine ait veri seti kullanılarak oluşturulan modelde "Türkiye'nin AB ile özel bir ticari ilişkisi var mı?" sorusunun cevabı çekim modeli kullanılarak test edilmiştir. Çalışmadan ortaya çıkan sonuçlar Türkiye ile $\mathrm{AB}$ arasında özel bir ticari ilişkinin olmadığını yönündedir. 
Karagöz ve Karagöz (2009), 2005 yılı verileri ve 169 ülkeye ait yatay kesit verisi kullanarak çekim modeli analizi yapılmıştır. Modelin sonuçlarına göre Türkiye dış ticaretindeki taraf ülkelerin ekonomik büyüklüğünden olumlu etkilenirken, nüfus ve mesafeden olumsuz etkilenmektedir. Taraf ülkenin Türkiye ile tarihsel, kültürel bağları, İslam ülkesi olması ticareti olumlu etkilerken; $A B$ üyeliği ve Karadeniz Ekonomik İşbirliği üyesi olması da ticareti arttırıcı yönde katkı yaptığı ve komşuluğun anlamlı etki doğurduğu sonucuna ulaşılmıştır.

Aysun $v d$. (2012), 1980-2009 dönemi Türkiye ile AB (15 ülke) arasındaki dış ticarete GB'nin etkide bulunup bulunmadığını panel çekim modeli uygulayarak araştırmıştır. Tahmin sonuçlarına göre GB'nin Türkiye'nin ithalatına önemli etkide bulunurken ihracatında etkisiz olduğu ortaya çıkmıştır.

Sorhun (2013), 1992-2012 dönemini kapsayan veri setini kullanarak Türkiye'nin yakın coğrafyasında yer alan ülkelerle olan dış ticareti incelenmiştir. Çalışmadan elde edilen bulgulara göre GSYIH, ortak sınır dış ticareti pozitif etkilerken mesafe, Arap Baharı ve 2008 krizi negatif etkilemiştir.

Sayg11 ve Manavgat (2014), 1995-2012 dönemine ait veriler kullanılarak Türkiye'nin yoğun ticaret yaptığı 30 ülke için Linder hipotezi geçerliliği çekim modeli analizi ile sınanmıştır. Analiz sonucunda elde edilen bulgular Linder etkisini ölçen değiş̧kenin Türkiye'nin ithalat yoğunluğu üzerinde belirgin bir etkisinin olduğu ancak ihracat üzerinde bu hipotezin desteklenmediği yönündedir.

Ülengin $v d$. (2015), 2005-2012 dönemi Türkiye ve AB (18) karayolu taşımacılığı üzerindeki kotaların dış ticaret hacmindeki etkisi panel çekim modeli kullanarak analiz edilmiştir. Karayolu kotalarının Türkiye'nin AB'ye yaptığı ihracat üzerinde anlamlı ve negatif etkisinin bulunduğu ayrıca kotaların olmadığı bir durumda daha yüksek ihracat değerlerine ulaşılabileceği ortaya çıkmıştır.

Işık (2016), Türkiye ve ŞiÖ arasındaki ticaret akış1 2004-2014 ait dönemi incelenmiş, 2007-2008 küresel ekonomik kriz, ortak dil, ortak sınır ve ortak ekonomik entegrasyona üyelik kukla değiş̧ken olarak modele eklenmiştir. Elde edilen sonuçlara göre ülkelerin GSYIH büyüklüğü, nüfus, ortak sınır ve ortak ekonomik entegrasyona üyelik ticareti pozitif etkilerken, mesafe ve küresel krizi olumsuz etkilemektedir.

\subsection{Veri Seti ve Model}

Bu çalışmada Türkiye'nin seçili örgütlere yönelik ihracat verileri kullanılmış, ithalat verileri dâhil edilmemiştir. Bu durumun temel nedeni Türkiye'nin özellikle teknoloji ve enerji ithalatında dışa bağımlı olması neticesinde teori de yer alan "mesafeler kısaldıkça ticaret hacmin artacağı" ilkesinin geçerli olmamasıdır. Teorinin 
temelinde yer alan ülkeler arasındaki ticaret hacmi ile coğrafi mesafe arasındaki negatif ilişki ülkelerin dış ticaret bağımlılıkları nedeniyle ortadan kalmaktadır (Tatlıcı, 2009: 71). Bu nedenle oluşturulan çekim modelinde sadece ihracat verileri kullanılmış, ithalat verileri dâhil edilmemiştir.

Oluşturulan modelde 1996-2015 yıllarına ait panel veri seti kullanılmıştır. Çalışmada zaman uzunluğu t: 20, ülke sayısı: 92 olarak toplamda n:1840 gözlem sayısına ulaşılmıştır. Modelde yer alan örgütler birinci bölümde ayrıntılı olarak ele alınan uluslararası örgütlerden seçilmiş olup ülke sayısı verilere ulaşılabilirlik ve ticari yoğunluk göz önünde tutularak belirlenmiştir. ${ }^{2}$ Stata 11 ekonometri programı kullanılmıştır.

\section{Model 1;}

$$
\operatorname{In} X_{i j, t}=\beta_{0}+\beta_{1} \operatorname{In} Y_{i, t}+\beta_{2} \operatorname{In} Y_{j, t}-\beta_{3} \operatorname{In} \operatorname{Mesafe}_{i j, t}+\varepsilon_{\mathrm{ij}}
$$

Model 1'de yer alan X, ülkeler arasındaki ihracatı ifade etmektedir. Milli gelir değişkeni Y ile gösterilmekle birlikte modele son olarak mesafe değişkeni eklenmiştir. Ekonometrik tahminleme metodu açısından ise, terimler logaritmik formatta yazılmıştır. Model daha yakından incelenirse $\mathrm{X}_{\mathrm{ij}, \mathrm{t}} \mathrm{i}$ ülkesinden $\mathrm{j}$ ülkesine $\mathrm{t}$ zamanında yapılmış olan ihracat verilerini ifade etmektedir. $Y_{i, t ;}$ i ülkesinin $t$ zamanındaki milli gelirini, $Y_{j t} ;$ ülkesinin t zamanındaki milli gelirini göstermektedir. Son olarak ülkelerin başkentleri arasındaki mesafe modele eklenerek basit bir çekim modeli elde edilmiştir.

\section{Model 2;}

In $X_{i j, t}=\beta_{0}+\beta_{1} \operatorname{InY}_{i t}+\beta_{2} \operatorname{InY}_{j t}-\beta_{3}$ In Mesafe $_{i j, t}+\beta_{4} A B+\beta_{5} N A F T A+\beta_{6} A P E C+$ $\beta_{7} A S E A N+\beta_{8} G C C+\beta_{9} A E C+\beta_{10} S T A+\varepsilon_{\mathrm{ij}, \mathrm{t}}$

$\mathrm{X}_{\mathrm{ij}, \mathrm{t}}$ : $\mathrm{t}$ zamanında i ülkesinden $\mathrm{j}$ ülkesine yönelik gerçekleştirilen ihracat

$\mathrm{Y}_{\mathrm{it}}$ : t zamanına ait Türkiye'nin GSYİH

$\mathrm{Y}_{\mathrm{jt}}$ : t zamanına ait diğer ülkelerin GSYİH

Mesafe: Başkentler arasındaki uzaklık (km)

AB: Avrupa Birliği ve GB temsil eden kukla değişken

NAFTA: Kuzey Amerika Serbest Ticaret Anlaşması kukla değişkeni

APEC: Asya Pasifik Ekonomik İşbirliği kukla değişkeni

ASEAN: Güneydoğu Asya Uluslar Birliği kukla değişkeni 
GCC: Körfez İşbirliği Teşkilatı kukla değişkeni

AEC: Afrika Ekonomik Topluluğu kukla değişkeni

STA: Serbest Ticaret Anlaşması kukla değişkeni

$\varepsilon=$ Hata terimi

Modelde yer alan değişkenler :

Ihracat: Türkiye'nin belirli yıllara ait seçili ülkelerle gerçekleştirdiği ihracat değerlerini ifade eden bağımlı değişkendir. Çalışmada kullanılan 1996-2015 yıllarına ait ihracat verileri TÜIK'ten alınmıştır.

GSYIHH: Bir ülkenin ekonomik büyüklüğünün ölçütü olan GSYİH, çekim modelinde ülkelerin arz ve talebi yerine kullanılan temsili bir değeri ifade etmektedir. Çalışmada kullanılan GSYİH değerleri Dünya Bankası veri tabanından dolar cinsinden alınmıştır. Ekonomik büyümede yaşanacak artışın ticareti pozitif yönde etkilemesi beklenmektedir.

Mesafe: Türkiye'nin başkenti Ankara ile ihracatı gerçekleştirdiği ülkelerin başkentleri arasındaki uzaklık $\mathrm{km}$ cinsinden hesaplanmıştır. Modelde ulaştırma maliyetlerini temsil eden bağımsız değişken verileri http://ec.europa.eu/dgs/education_culture/tools/distance_en.htm linkinden alınmıştır. Ülkeler arasındaki mesafenin ulaştırma maliyetlerini artıracağı için ticareti negatif yönde etkilemesi beklenmektedir.

Ekonomik Örgütler: AB, NAFTA, APEC, ASEAN, GCC ve AEC üyesi ülkelerin yer aldığı kukla değişkenlerdir. Çalışmada yer alan ülkeler ait oldukları birliğin üyesi ise 1 diğer hallerde 0 değerini almıştır. Elde edilecek sonuçların pozitif çıkması beklenmektedir.

$G B$ - STA: Türkiye'nin en önemli ticari ortaklarından biri olan AB modele eklenerek aynı zamanda GB'nin ihracattaki etkisi incelenmek istenmiştir. Ayrıca serbest ticaret anlaşmaları da modele kukla değişken olarak eklenerek GB ile karşılaştırılması düşünülmüştür. Elde edilecek sonuçların pozitif çıkması beklenmektedir.

\subsection{Tahmin Sonuçlarının Değerlendirilmesi}

Panel veriler yatay kesit verileri ve zaman serisi verilerini birleşmesiyle oluşmaktadır. Bir zaman serisinin istatiksel analizi yapılmadan önce serinin zaman içerisinde durağan olup olmadığının incelenmesi gerekmektedir. Durağan olmayan serilerle yapılan analizler sahte regresyona sorununa neden olmakta, bu serilerle yapılan 
$\mathrm{t}$ - F testleri ve $\mathrm{R}^{2}$ değerleri güvenilirliğin dişında sapmalı sonuçlar verebilmektedir. Bunun nedenle öncelikte çalışmada kullanılan serilerin durağanlığı test edilmiş, Hadri (2000) ve Levin $v d$. (LLC) (2002) tarafından geliştirilen birim kök testleri kullanılmıştır.

Tablo 2. Birim Kök Testi

\begin{tabular}{|l|c|l|}
\hline Değişkenler & Hadri & LLC \\
\hline $\operatorname{lnİhracat~}$ & 89.3106 & -5.6422 \\
& $(0.0000)^{* * *}$ & $(0.0000)^{* * *}$ \\
\hline $\ln \mathrm{Y}_{\mathrm{i}}$ & 103.9334 & -17.8826 \\
& $(0.0000)^{* * *}$ & $(0.0000)^{* * *}$ \\
\hline $\ln \mathrm{Y}_{\mathrm{j}}$ & 102.0173 & -9.8633 \\
& $(0.0000)^{* * *}$ & $(0.0000)^{* * *}$
\end{tabular}

$* * * 0.01, * * 0.05, * 0.10$, anlamlılık düzeylerini ifade etmektedir. (Olasılık değerleri parantez içerisinde verilmiştir)

Yapılan birim kök test sonuçlarına göre seriler birim kök içermemektedir. Ortaya çıkan tabloda ihracat verilerinin, Türkiye'ye ait GSYİH verilerinin ve diğer ülkelere ait GSYİH verilerinin logaritmik formda durağan olduğu görülmektedir. Serilerin durağan olması sebebiyle durağan olmayan zaman serileri arasındaki ilişkiyi çözmek için kullanılan panel eşbütünleşme uygulanmasına gerek duyulmamıştır.

Genel anlamda panel veri analizinde iki farklı tahmin yöntemi bulunmaktadır. Bunlar sabit etkiler (fixed effect) modeli ve rassal etkiler (random effect) modelidir. Sabit etkiler modelinde, sabit katsayı her kesit sayısına göre değişiklik gösterirken, rassal etkiler modelinde katsayı tesadüfi bir şekilde kesitten kesite değiştiği için asıl önem merak edilen değişkenlerin katsayılarına verilmektedir (Golovko, 2009: 12). Literatürde yapılan çalışmalarda tahmin yöntemlerinden hangi modelin seçileceğine dair Hausman Testi uygulanmaktadır.

Hausman test istatistiği tesadüfi etkiler tahmincisi sıfır hipotezi altında $\mathrm{k}$ serbestlik dereceli ki-kare dağılımını göstermektedir. Yapılan Hausman testi sonucunda test istatistiği 0.24 olarak bulunmuş olup olasılık değeri $(p=0.8860) p>0.1$ anlam düzeyinde kabul edilmektedir. Bu nedenle rassal etkiler modeli, sabit etkiler modeline tercih edilmiştir. ${ }^{3}$ Hâlihazırda model içerisinde zamanla değişmeyen mesafe ve uluslararası ekonomik örgütler (dummy variable) gibi değişkenler de mevcuttur. $\mathrm{Bu}$ değişkenlerin tahmin edilmesinde rassal etkiler modeli daha geçerli hale gelmektedir.

Model için uygulanacak tahminci belirlendikten sonra, ele alınan modelde değişen varyans ve otokorelasyon varlığı test edilmiştir. Değişen varyans hata terimleri varyansının sabit olmadığı ve değişkenlerin bu durumdan etkilendiğini ifade eder. (Bu durumda En Küçük Kareler (EKK) tahmincileri sapmasız ve tutarlıdır ancak minimum 
varyansı ifade eden etkinlik varsayımı ortadan kalkar.) Değişen varyans problemini saptamada literatürde bazı testler kullanılmaktadır. $\mathrm{Bu}$ testlerden en yaygın kullanılanları Breusch - Pagan ve White testleridir.

Tablo 3. Değişen Varyans Testi

\begin{tabular}{|c|c|c|}
\hline & Breusch Pagan /Cook Weisberg & White Test \\
\hline Ki kare & 108.00 & 348.26 \\
\hline P Olasılık & $(0.0000) * * *$ & $(0.0000)^{* * * *}$ \\
\hline
\end{tabular}

Tablo 3'te yer alan Breusch-Pagan/Cook Weisberg ve White test sonuçları birbiriyle paralellik göstermekle birlikte sabit varyans sifir hipotezi $(p=0.0000) p<0.1$ anlam düzeyinde reddedilmektedir, bu nedenle modelde değișen varyans sorunu bulunmaktadır. Modelde otokorelasyon sorunu olup olmadığı Durbin Watson ve Breusch-Godfrey testleri kullanılarak sınanmıştır. Test sonuçları paralellik göstermekle birlikte Breusch Godfrey testi sonucunda ki-kare 1248.721 olasılık değeri $(p=0.000) p$ $<0.1$ olup $\mathrm{H}_{0}$ hata terimleri arasında otokorelasyon yoktur hipotezi reddedilmektedir. $\mathrm{Bu}$ durumda modelde değişen varyans sorununa ek olarak otokorelasyon sorunu da bulunmaktadır.

Değişen varyans, otokorelasyon veya birimler arası korelasyon sorunlarının varlığ durumunda parametre tahmincileri etkin değildir, başka bir ifade ile varyanslardan elde edilen tahminci standart hataları, $t$ ve $F$ istatistikleri, $R^{2}$ ve güven aralıkları da geçerliliğini yitirmektedir. Bu nedenle değişen varyans, otokorelasyon veya birimler arası korelasyonun en az birisinin varlığ 1 durumunda parametre tahminlerine dokunmadan standart hatalar düzeltilmeli, dirençli standart hatalar elde edilmelidir (Tatoğlu, 2013: 241). Bu konuda Arellano (1987), Froot (1989) ve Rogers (1993) parametreleri değiş̧irmeden dirençli (robust) standart hatalar elde etmeyi olanak sağlayan bir tahminci geliştirmişlerdir. Bu nedenle model dirençli standart hatalar elde edilerek yeniden tahmin edilmeli ve bu şekilde yorumlanmalıdır (Parlakyıldız ve Güvel, 2015: 394 - 404). Bu nedenle çalışmanın devamında sadece standart hataları düzeltilmiş rassal etkiler dikkate alınmış ve değişkenler bu yönde açıklanmıştır. 
Tablo 4. Model Tahmin Sonuçları

\begin{tabular}{|c|c|c|}
\hline Açıklayıcı Değişkenler & Sabit Etkili & Rassal Etkili * \\
\hline Sabit & $\begin{array}{l}-37.8711 * * * \\
(0.8375585)\end{array}$ & $\begin{array}{l}-30.4223 * * * \\
(2.441291)\end{array}$ \\
\hline In $Y_{i}$ & $\begin{array}{l}1.5752 * * * \\
(0.0516988)\end{array}$ & $\begin{array}{l}1.5583 * * * \\
(0.0936185)\end{array}$ \\
\hline $\ln Y_{i}$ & $\begin{array}{l}0.3040 * * * \\
(0.0620125)\end{array}$ & $\begin{array}{l}0.3287 * * * \\
(0.052545)\end{array}$ \\
\hline ln Mesafe & & $\begin{array}{l}-1.0759 * * * \\
(0.2286193)\end{array}$ \\
\hline $\mathrm{AB}$ & & $\begin{array}{l}1.5482 * * * \\
(0.4575864)\end{array}$ \\
\hline APEC & & $\begin{array}{l}1.4919 * * \\
(0.612289)\end{array}$ \\
\hline AEC & & $\begin{array}{l}1.2572 * * \\
(0.5432304)\end{array}$ \\
\hline GCC & & $\begin{array}{l}1.0534 * \\
(0.590339)\end{array}$ \\
\hline NAFTA & & $\begin{array}{l}0.7843 \\
(0.6542513)\end{array}$ \\
\hline ASEAN & & $\begin{array}{l}-1.3916 * * * \\
(0.4656235)\end{array}$ \\
\hline STA & & $\begin{array}{l}1.006^{* * * *} \\
(0.3665494)\end{array}$ \\
\hline $\begin{array}{l}R^{2} \text { within } \\
R^{2} \text { between }\end{array}$ & 0.68 & 0.68 \\
\hline $\mathrm{R}^{2}$ overall & $\begin{array}{l}0.60 \\
0.61\end{array}$ & $\begin{array}{l}0.80 \\
0.78\end{array}$ \\
\hline F/Ki kare/ & $1843.33 * * *$ & $1112.81 * * *$ \\
\hline
\end{tabular}

*Dirençli standart hatalar düzenlenmiş şekliyle belirtilmiştir. ${ }^{* * *} 0.01, * * 0.05,{ }^{*} 0.10$, anlamlllık düzeylerini ifade etmektedir. Standart hatalar parantez içerisinde yer almaktadır.

Yeniden tahmin edilen model ile elde edilen veriler karşılaştırıldığında katsayı tahminlerinin aynı kaldığı ancak belirtilen standart hataların farklı olduğu gözlenmiştir. Modelin bir bütün olarak anlamlı olduğunu ifade eden $\mathrm{F}$ değeri \%1 düzeyinde anlamlı çıkmıştır ayrıca rassal etkilerle tahmin edilen modelde bağımsız değiş̧kenlerin bağımlı değişkeni açıklama oranı $\left(\mathrm{R}^{2}\right) \% 80$ 'dir. Elde edilen sonuçlar;

GSYIH $\left(\boldsymbol{Y}_{\boldsymbol{i}}\right)$ : Modelin temel değişkenlerini arasında yer alan ve Türkiye'nin milli gelirini ifade eden GSYİH katsayısı \%1 düzeyinde anlamlı ve pozitif çıkmıştır. Modelde yer alan bu değişken Türkiye'nin sahip olduğu üretim kapasitesi ve ürün 
çeşitliliğinin bir göstergesi olarak kabul edilmektedir. Ülkenin sahip olduğu üretim kapasitesi ve ürün çeşitliliğindeki artı̧ın ihracatı arttırması beklenmektedir. Elde edilen tahmin sonuçlarına göre ihracatı gerçekleştiren ülke konumunda olan Türkiye'nin GSYIH meydana gelen \%1'lik artış seçili ülkelere yönelik ihracatı $\% 1.55$ oranında artırmaktadır.

GSYiH $\left(\boldsymbol{Y}_{j}\right)$ : Türkiye'nin ihracat yaptığı ülkelerin milli gelirlerini ifade eden GSYİH katsayısı \%1 düzeyinde anlamlı ve pozitif çıkmıştır. Modelde ithalatçı konumundaki ülkelerin yer aldığı bu değişken taraf ülkelerin satın alma gücünün bir göstergesi olarak kabul edilmektedir. Bu ülkelerin milli gelirlerinde yaşanan artışın bu ülkelerin gerçekleştirdiği ithalat oranını artırması beklenmektedir. Türkiye'nin ihracat yaptığı ithalatçı ülkelerin GSYIH'sında meydana gelen \%1'lik artı̧ Türkiye ihracatında $\% 0.32$ oranında artışa neden olmaktadır.

Mesafe: Teorideki temel değiş̧kenlerinden biri olan mesafe değişkeni $\% 1$ düzeyinde anlamlı ve negatif çıkmıştır. Ülkelerin başkentleri arasındaki uzaklığı ifade eden katsayının taşıma maliyetlerini artırdığı için dış ticareti çift taraflı olumsuz yönde etkilemesi beklenmektedir. Taraflar arasındaki mesafenin \%1'lik artı̧ı ihracatın \%1.07 oranında azalmasına neden olmaktadır. Mesafe değişkenin ihracat üzerindeki etkisinin bu derece yüksek olmasının temel nedeni seçilen ülkelerin dünyanın değişik kıtalarda yer almasidir.

Böylece teorinin en önemli iki değişkeni (milli gelir ve mesafe) ile ilgili beklenen sonuçlar elde edilmiştir. Dünyanın çeşitli bölgelerinde yer alan ülkelerin ekonomik birliklere dâhil olma durumlarının Türkiye dış ticaretini nasıl etkilediği kukla değişkenlerle tahminlenmiştir.

$\boldsymbol{A B}$ : İlk olarak $\mathrm{AB}$ 'ye üye olan ülkelerin yer aldığı kukla değişken beklendiği gibi istatistiki açıdan anlamlı ve pozitif çıkmıştır. Türkiye'nin ihracat yaptığı seçili ülkeler göz önüne alındığında ithalatçı ülkenin $\mathrm{AB}$ üyesi olması ihracatı $\% 1.54$ oranında artırmaktadır. $\mathrm{Bu}$ durum $\mathrm{AB}$ 'ye üyelik için mücadele veren, $\mathrm{GB}$ üyesi Türkiye için beklenen bir durumdur. Gerek birlik öncesi gerek birlik sonrası Türkiye'nin en büyük ticaret ortağı konumunu sürdüren $\mathrm{AB}$ ile diğer örgütler karşılaştırıldığında ihracat açısından en yüksek ağırlığa sahip ülkeler $\mathrm{AB}$ ülkelerdir. $\mathrm{Bu}$ durumun temel nedenleri arasında $\mathrm{AB}$ ile dış ticarette $\mathrm{GB}$ müktesebatının geçerli olması, ticaretin büyük çoğunluğunun Avrupa eksenli gerçekleşmesi, taraflar arasında dil problemlerinin daha az yaşanması, işadamların pazar araştırmasında zorlanmaması, birliğin coğrafi yakınlıksorunsuz sınır komşuluğu nedeniyle elde ettiği avantajlar sayılabilir.

APEC: APEC'e üye olan ülkelerin yer aldığı kukla değişken beklendiği gibi \%5 düzeyinde anlamlı ve pozitif çıkmıştır. İhracat yapılan ülkenin APEC üyesi olması 
Türkiye'nin ihracatını \%1.49 oranında artırmaktadır. Tüm ülkeler düşünüldüğünde ihracatı gerçekleştirilen ticari partnerin APEC ülkesi olması AB sonra en yüksek düzeye sahiptir. $\mathrm{Bu}$ durumun temel nedeni küresel ekonomide gittikçe artan güce sahip AsyaPasifik ülkelerinden ABD, Çin, Rusya, Güney Kore ve Japonya gibi ekonomisi güçlü ülkelerin Türkiye ihracatında için önemli bir yer tutmasıdır. Diğer bütünleşmeler arasında $A B$ 'den sonra Türkiye'nin ihracatında en büyük ağırlı̆ga sahip olan örgüt APEC'tir.

AEC: Afrika kıtasında yer alan ve Türkiye ticaret hacminde önemli bir yere sahip 35 seçili ülkeyi temsil eden kukla değiş̧keni beklendiği gibi $\% 5$ düzeyinde anlamlı ve pozitif çıkmıştır. İhracat yapılan ülkenin AEC üyesi olması Türkiye'nin ihracatı $\% 1.25$ oranında artırmaktadır. Bu durum temel nedeni Türkiye'nin özellikle Afrika açılımı sonrası bölgeye ilgisinin artması, Afrika ile ortaklık politikasının hayata geçirilmesi ve buna mukabil ticaret hacminde artış yaşanmasıdır.

GCC: Körfez ülkelerinin yer aldığı GCC kukla değişkeni beklendiği gibi \%10 düzeyinde anlamlı ve pozitif çıkmıştır. Türkiye'nin ihracat yaptığı ülkeler göz önüne alındığında bu ülkelerin GCC üyesi olması ihracatı $\% 1.05$ oranında artırmaktadır. Petrol ve doğal gaz zengini olan bu ülkelerin tüketim harcamalarının artması, Türkiye'nin son yıllarda artan altyapı ve inşaat sektörüyle bölgede daha fazla yer alması ve Türkiye'nin stratejik ortak ilan edilmesi bu durumun başlıca nedenleri arasında sayılabilir.

NAFTA: Kuzey Amerika ülkelerin yer aldığı kukla değişken pozitif ancak anlamsız çıkmıştır.

ASEAN: ASEAN'a üye olan ülkelerin yer aldığı kukla değişken $\% 1$ düzeyinde anlamlı ancak negatif çıkmıştır. Modelde yer alan diğer birlikler düşünüldüğünde Türkiye'nin ticari iliş̧kilerinin en alt düzeyde gerçekleştiği birlik ASEAN'dır. Ortaya çıkan sonuç Türkiye'nin birlik ile ihracatının çok düşük olduğu, bu durumun Türkiye ihracatını olumsuz etkilediği yönündedir. Bu durumun temel nedenleri birliğin güçlü ekonomiye sahip ülkelerce çevrili olması, tüketim eğilimlerinin ve pazar yapılarının farklı olması, dil farklılıkları ve coğrafi uzaklık olarak sayılabilir.

STA: Türkiye'nin serbest ticaret anlaşması imzaladığı ülkeleri temsil eden kukla değişken beklendiği gibi \%1 düzeyinde anlamlı ve pozitif çıkmıştır. İhracat yapılan ülke ile serbest ticaret anlaşması imzalanması durumu Türkiye ihracatını \%1.006 oranında arttırmaktadır. Bu durumun temel nedeni taraflar arasinda ticareti engelleyici kota ve tarife benzeri kısıtlayıcıları ortadan kaldırarak ticareti karşılıklı kolaylaştırılmasıdır.

Ekonomik işbirliği ve bütünleşme aşamaları göz önüne alındığında serbest ticaret anlaşmalarının bir sonraki adımı GB olmakla birlikte daha geniş etkilere sahiptir. 
Çalışmada $\mathrm{AB}$ kukla değişkeni ile temsil edilen GB'nin ihracata etkisi \%1.54'dür. Modele dâhil edilen STA ülkelerinin ihracata etkisi \%1.006'dır. Bu durum Türkiye'nin ihracatında serbest ticaret anlaşması imzaladığı ülkeler yerine GB ülkelerine daha fazla ağırlık verdiği, bu ülkelerle ihracat yapma potansiyelinin daha yüksek olduğu şeklinde açıklanabilir. Ortaya çıkan sonuç teori ile paralellik göstermekle birlikte imzalanan GB anlaşmasının ihracatı STA'dan daha büyük oranda arttırdığı sonucuna ulaşılabilir.

\section{SONUÇ}

Günümüz ekonomisinde dünya bir yandan küreselleşirken diğer bir yandan bölgeselleşmektedir. Özellikle II. Dünya Savaşı sonrasında tarih sahnesine yeni aktörler dâhil olmuş, sistemde daha güçlü olarak yer alan ekonomik örgütler ise zamanla ticari blokların oluşmasına neden olmuştur. Ortaya çıkan bu durum Türkiye gibi gelişmekte olan ülkeler için daha fazla önem arz etmektedir. Bu ülkelerin hangi ticari blokta yer alacağı veya hangi ticari blokla ticari ilişkilerini geliştirmesi gerektiği sürekli tartışılmaktadır.

Cumhuriyetin ilanından günümüze kadar devam eden "muasır medeniyetler seviyesine ulaşma" hedefi ile Türkiye iç ve dış politikasını, ekonomik ve sosyal yapısını yeniden şekillenmiştir. Konjonktürel dönüşümden kendi payına düşeni alan Türkiye bu süre zarfında batı menşeli örgütlere üye olmuş ayrıca Avrupa'nın en geniş bütünleşme hareketi olan AB'ye karşı da kayıtsız kalmamıştır. Ancak üyelik müzakerelerinde ilerleme kaydedilememesi Türkiye'de hayal kırıklığı yaratmış, zamanla taraflar arasında yaşanan siyasi - ekonomik sorunlar da ilişkileri olumsuz yönde etkilemiştir. Sonuç olarak ilişkilerin durgun seyrettiği bu süre zarfinda Türkiye için $\mathrm{AB}$ karşısında alternatif olabilecek örgütler sorgulanmıştır.

1996-2016 yılı ticari veriler ele alındığında seçili örgütler arasında ticaret hacminin en yüksek olduğu birlik $\mathrm{AB}^{\prime}$ 'dir. Gerek ihracat gerekse ithalat verilerinde $A B$ 'nin toplam payı incelendiğinde benzer şekilde en yüksek pay oranı $A B$ aittir. Örgütler arasında ticaret hacminde ikinci sırayı APEC almakla birlikte, Türkiye'nin toplam ithalatında sahip olduğu pay oranı dikkat çekicidir. NAFTA'nin toplam ihracattaki payı yıllar içerisinde azalmış buna mukabil GCC ve AEC'nin pay oranları ise artış göstermiştir. Bu birliklerin ithalat hacmi zamanla artış göstermiş olmasına karşın Türkiye'nin toplam ithalatında elde ettikleri pay oranları belirgin bir değişim göstermemiştir. Seçili örgütler göz önüne alındığında birlikler arasında en düşük ticaret hacmi ve pay oranına sahip olan örgüt ASEAN'dır.

GB sonrası ele alınan verilerle yapılan çekim modeli sonuçları incelendiğinde, Türkiye ihracatının gerek Türkiye'nin gerekse birlik üyesi ülkelerin milli gelirlerinde yaşanan değişimle pozitif olarak sıkı sıkıya bağlı olduğu gözlenmiştir. Teoriyle paralel 
bir şekilde taraflar arasındaki mesafenin ticareti olumsuz yönde etkilediği, ihracatın gelişmesinde engelleyici rol üstlendiği teyit edilmiştir. Türkiye'nin yakın ve uzak coğrafyasında yer alan ve birçok kıtayı kapsayan ekonomik örgütlerin ihracat üzerindeki etkisini analiz etmeye yönelik modele eklenen kukla değiş̧enler (NAFTA ve ASEAN dışında) pozitif ve anlamlı bulunmuştur. AB, APEC, GCC ve AEC birliklerine üye olan ülkelerin Türkiye ihracat hacminde önemli konumda bulunduğu ve ihracatı olumlu etkilediği gözlenmiştir.

Modelde yer alan birlikler içerisinde diğer örgütlerle kıyaslandığında ağıllıklı konuma sahip olan örgütün $\mathrm{AB}$ olduğu teyit edilmiştir. $\mathrm{Bu}$ durumun özellikle $\mathrm{GB}$ anlaşması ile Türk menşeli ürünlerin (tarım ürünleri hariç) birlik içerisinde serbestçe dolaşma hakkı elde etmiş olmasına bağlanmaktadır. Elde edilen bulgular AB sonra Türkiye ihracatında en önemli konuma sahip olan örgütün APEC olduğu ayrıca gerek GCC gerekse AEC ülkelerinin ihracattaki etkilerinin göz ardı edilmemesi gerektiği yönündedir. Gelecek hedefleri arasında çok yönlü dış ticaret politika uygulaması bulunan Türkiye'nin ticari ortak olarak bu birlikleri esas alması büyük oranda ihracata katk1 sağladığı sonucuna ulaşılmıştır. AB temsil ettiği gibi GB de temsil eden kukla değişken pozitif ve anlamlı bulunmuştur. Benzer şekilde STA kukla değişkeni de pozitif ve anlamlı bulunmuştur. Ortaya çıkan sonuç STA'nın Türkiye ihracatı üzerinde olumlu etkileri olduğu ancak GB'nin Türkiye'nin ihracatı üzerindeki etkisinin daha büyük olduğu yönündedir.

Elde edilen sonuçlar ve konjonktürel durum birlikte değerlendirildiğinde; küresel değişim ve dönüşümlerin yaşandığ 1 , yeni güç dengelerinin oluştuğu bu ortamda atılacak yeni adımlar geleceğin şekillenmesinde etkili olacaktır. Kıtalar arasında köprü konumunda olan bir ülkenin ticari ilişkilerinde sadece tek bir pazara yönelmesinin uygun bir politika olmadığının farkına varılmasıyla çalışmalara başlanmış, uygulanan politikalar neticesinde Asya, Ortadoğu ve Afrika'da yer alan ülkelerin Türkiye'nin öncelik verdiği ülkeler kategorisinde yer almaya başladığı görülmüştür. Böylece ticari bloklar arasında denge kurmayı amaçlayan çalışmalar günümüzde devam etmekle birlikte ortaya çıkan sonuçların dış ticaret hacminde atışa neden olması beklenmektedir.

\section{NOTLAR}

${ }^{1}$ Günümüzde etkinliğine devam eden birçok bölgesel ekonomik örgüt bulunmaktadır. $\mathrm{Bu}$ örgütlerden bazıları şu şekilde sıralanabilir: Avrupa Serbest Ticaret Bölgesi (EFTA), Güney Ortak Pazarı (MERCOSOR), Latin Amerika Serbest Ticaret Bölgesi (LAFTA) Karayipler Topluluğu (CARICOM), Mağrip Arap Birliği (MAB), And Milletler Topluğu (ANDEAN) ...

${ }^{2}$ AB: Fransa, Hollanda, Almanya, İtalya, Danimarka, İngiltere, Yunanistan, Portekiz, İspanya, Avusturya, Finlandiya, İsveç, Çek Cumhuriyeti, Malta, Litvanya, Macaristan, Polonya, Slovakya, Slovenya, Bulgaristan, Romanya, Hırvatistan. 
NAFTA: ABD, Kanada, Meksika.

APEC: Avustralya, Brunei, Kanada, Endonezya, Japonya, Malezya, Filipinler, Yeni Zelenda, Singapur, Güney Kore, ABD, Tayland, Çin, Meksika, Şili, Peru, Rusya, Vietnam.

ASEAN: Brunei, Endonezya, Filipinler, Kamboçya, Laos, Malezya, Singapur, Tayland, Vietnam

GCC: Bahreyn, Kuveyt, Umman, Katar, Suudi Arabistan, BAE.

AEC: Mısır, Etiyopya, Nijerya, Zimbabwe, Güney Afrika Cumhuriyeti, Tunus, Gana, Sudan, Liberya, Senegal, Fildişi Sahilleri, Kamerun, Benin, Kongo, Mali, Burkina Faso, Nijer, Gambiya, Gine, Sierra Leone, Togo, Gabon, Kongo Demokratik Cumhuriyeti, Burundi, Angola, Cibuti, Kenya, Uganda, Tanzanya, Mozambik, Mauritius, Zambia, Malavi, Namibya.

STA: Malezya, Singapur, Güney Kore, Şili, Mısır, Tunus, Mauritius, İsrail, İsviçre, Gürcistan, Fas, Ürdün, Lübnan.

${ }^{3}$ Ayrıca havuzlanmış model (pool) ile rassal model arasında seçim yapmamıza imkân sağlayan Breusch-Pagan Lm test sonucu Hausman testi ile paralellik göstermekte, model tahminlemesinde rassal etkilerin daha uygun olacağı yönündedir.

\section{KAYNAKÇA}

Aitken, N. (1973), "The Effects of the EEC and EFTA on European Trade: A Temporal Cross Section Analysis", The American Economic Review, 63(5), 881-892.

Antonucci, D., S. Manzocchi (2006), "Does Turkey have a Special Trade Relation with the EU? Agravity Model Approach”, Elsevier, Economic Systems, (30), 157-169.

Arellano, M.(1987), "Practitioners' Corner: Computing Robust Standart Errors for Within-Groups Estimators", Oxford Bulletin of Economics and Statistics, 49(4), 431- 434.

Aysun, A., O. Öksüzler, M. Yılgör (2012), “Gümrük Birliği’nin Türkiye’nin Dış Ticareti Üzerine Etkisi:Panel Çekim Modeli Uygulaması”, Eskişehir Osmangazi Üniversitesi Sosyal Bilimler Dergisi, 13(2), 15-26.

Froot K. A. (1989), "Consistent Covariance Matrix Estimation with Cross-Sectional Dependence and Heteroskedasticity in Financial Data " Journal of Financial and Quantitative Analysis, 24(3), 335- 355

Golovko, A. (2009), Çekim Modeli: Avrasya Ülkelerinin Dış Ticareti. Anadolu İktisat Kongresi, Eskişehir, http://www.academia.edu/375375/cekim modeli avrasya ulkelerinin dis ticareti, E.T.: 28.12.2017.

Hadri, K. (2000), "Testing for Stationarity in Heterogeneous Panel Data", The Econometrics Journal, 3(2), 148-161

Işık, N. (2016), “Türkiye ile Şanghay İşbirliği Örgütü Arasındaki Ticaret Akımlarının Panel Çekim Modeli İle Analizi”, International Journal of Economic and Administrative Studies, 151-174.

Karagöz, M., K. Karagöz (2009), “Türkiye'nin Küresel Ticaret Potansiyelleri: Çekim Modeli Yaklaşımı”, Cumhuriyet Üniversitesi İktisadi ve İdari Bilimler Dergisi, 10(2), 127-144. 
AKÇAY, SAYGILI | An Application of Gravity Model on Turkey's Exports with Regional Economic...

Levin, A., F.C. Lin, S.C.J. Chu (2002), "Unit Root Tests in Panel Data: Asymptotic and FiniteSample Properties", Journal of Econometrics, (108), 1-24.

Linnemann, H. (1966), An Econometric Study of International Trade Flows, North Holland, Amsterdam.

Nowak-Lehmann, F., I. Zarzoso Martinez (2003), “Augmented Gravity Model: An Empirical Application to Mercosur- European Union Trade Flows", Journal of Applied Economics, (6), 291-316.

Nowak-Lehmann, F., D. Herzer, I. Zarzoso Martinez, S. Vollmer (2007), "The Impact of a Customs Union between Turkey and the EU on Turkey's Exports to the EU', Journal of Common Market Studies, 45(3), 719-743.

Özdemir, Ö. (22.11.2016), “Şanghay İşbirliği Örgütü'nün, Türkiye'ye Ekonomik Katkısı Olur mu?”, BBC Türkçe Köşe Yazısı,

https://www.bbc.com/turkce/haberler-turkiye-38067632, E.T.:28.12.2017.

Porojan, A. (2001), Trade Flows and Spatial Effects: The Gravity Model Revisited, Open Economies Review, (12), 265-280.

Poyhonen, P. (1963), "A Tentative Model for the Volume of Trade between Countries", Weltwirtschaftliches Archive, (90), 93- 100.

Rogers, W.H. (1993), "Regression Standard Errors in Clustered Samples", Stata Technical Bulletin, (13), 19-23

Saygıl1, F., G. Manavgat (2014), “Linder Hipotezi:Türkiye'nin Dış Ticareti için Ampirik Bir Analiz”, Ege Akademik Bakış, 14(2), 261-270.

Sorhun, E. (2013), “Türkiye'nin Eksik Dış Ticareti, Ticari Potansiyeli ve Yeni Fırsatlar”, Dokuz Eylül Üniversitesi İktisadi ve İdari Bilimler Fakültesi Dergisi, (28), 25-47.

Steger, M.B. (2006), Küreselleşme, Ankara: Dost Yayınları.

Parlakyıldız, F.M., A. Güvel (2015), '’Politik Sistemler ve Doğrudan Yabancı Sermaye Yatırımları Arasındaki İlişki”, Akademik Sosyal Araştırmalar Dergisi, (16), 386-407.

Tatlıcı, Ö. (2009), “Çekim Modeli: Türkiye'nin İhracatı Üzerine Bir Uygulama”, Atatürk Üniversitesi Sosyal Bilimler Enstitüsü, Yüksek Lisans Tezi, Erzurum.

Tatoğlu, F.Y. (2013), Panel Veri Ekonometrisi Stata Uygulamalı, İstanbul: Beta Basım Yayım Dağıtım.

Tinbergen, J. (1954), International Economic Integration, London: Elsevier.

Tüfekçi, Ö. (15.02.2016), "Son Gelişmeler Işı̆̆ında Türkiye ve Avrasya Ekonomik Birliği İlişkileri”, Avrasya Ekonomik İlişkileri Derneği Yazısı, http://ekoavrasya.net/duyuru.aspx?did=212\&Lang=TR, E.T.:28.12.2017.

Ülengin, F., B. Cekyay, P.T. Palut, B. Ulengin, Ö. Kabak, O. Ozaydin, S.O. Ekici (2015), "Effects of Quotas on Turkish Foreign Trade: A Gravity Model”, Transport Policy, (38), 1-7. 